\title{
GREEN ARCHITECTURE CONCEPTS APPLIED TO WANAKOTA APARTMENTS
}

Penerapan Green Architecture Pada Apartemen Wanakota

\author{
Andiyan $^{1}$; Abdul Gani Alfarizi ${ }^{2}$ \\ 1,2 Department of Architecture, Faculty of Science and Engineering, Universitas Faletehan \\ JI.Parakan Resik No.2 Bandung, Jawa Barat \\ 1andiyanarch@gmail.com; 2alfarizigani2@gmail.com
}

\begin{abstract}
The shrinking land in urban areas and the worsening world climate crisis have created a new residential development problem. One way to maximize land designated for residential use is to build vertical housing, such as constructing flats and apartments to accommodate more residents in a limited area. However, it also creates new problems because the energy required for a building will be extensive. The application of Green Architecture is an effort to reduce energy use for buildings and reduce the negative impact of buildings on the environment. one helpful reference is applying green architectural concepts. The apartment Wanakota is designed using the green building concept with the Indonesian Green Building Council (GBCl). Wanaka means City Forest, and trees inspire this name as trees. This tree is not only an aesthetic enhancer but as a CO2 absorber and oxygen supplier in the environment.
\end{abstract}

Keywords: climate crisis, housing, apartment, green architecture.

\begin{abstract}
Abstrak
Menyusutnya lahan di kawasan perkotaan dan memburuknya krisis iklim dunia telah menciptakan masalah pembangunan perumahan baru. Salah satu cara untuk memaksimalkan penggunaan lahan yang diperuntukkan untuk hunian adalah dengan membangun hunian vertikal, seperti membangun rumah susun dan apartemen yang dapat menampung lebih banyak penghuni di area yang terbatas. Namun juga menimbulkan masalah baru karena penggunaan energi yang dibutuhkan untuk suatu bangunan akan sangat besar. Penerapan Green Architecture merupakan upaya untuk mengurangi penggunaan energi untuk bangunan dan mengurangi dampak negatif bangunan terhadap lingkungan. salah satu referensi yang membantu adalah menerapkan konsep arsitektur hijau. Apartemen Wanakota didesain menggunakan konsep green building bersama Indonesian Green Building Council (GBCl). Wanaka berarti Hutan Kota, dan pohon menginspirasi nama ini sebagai pohon. Pohon ini tidak hanya sebagai penambah estetika tetapi sebagai penyerap $\mathrm{CO} 2$ dan pemasok oksigen di lingkungan.
\end{abstract}

Kata kunci: krisis iklim, perumahan, apartemen, arsitektur hijau.

\section{Introduction}

The limited land in urban areas combined with the expanding population is an issue that often happens in large cities. Due to the growing demand for housing and the scarcity of available land, land or the cost of an urban house is very costly(Balaras, C. A., Droutsa, K., Argiriou, A. A., \& Asimakopoulos, 2000)
Apart from limited land, large cities face many complex environmental issues, including access to clean water, air pollution, and a dearth of green space and water absorption(Akmal, 2007).

With growing issues, development specialists and environmental activists are not remaining mute, actively seeking and studying remedies and solutions to these concerns. 
Vertical housing is one solution for metropolitan regions' limited residential space. A stand-alone dwelling, such as an apartment may house more occupants. Vertical occupancy may effectively fix difficulties in congested locations if the proper design is used(Cohen, S., Glass, D. C., \& Singer, 1973).

However, vertical housing has several drawbacks, including high energy usage. Green design is advantageous for vertical housing such as flats since it helps reduce energy consumption, greenhouse gas emissions, water treatment, and air quality(Slezkine, 1994).

Other large cities around the nation are actively promoting and using the notion of green or sustainable design. This is a response to the looming climate problem and an endeavor to improve the quality of homes and the urban environment. This study is anticipated to serve as a reference for his future work and may be expanded to a larger scale (Andiyan,Nurrisman, 2021)

\section{Methodology}

The Wanakota Apartment is created using a green architectural concept, prioritizing green architectural concepts in the layout. A technique is required throughout the data collection and analysis phases. The data will be used to develop and build the residence. The data collection procedure involves field surveys and precedent studies to ascertain the apartment's activity patterns and space needs. The second phase is data analysis, which involves extracting data from all available sources and summarizing the findings. The third phase is a synthesis of the findings drawn from the previous stages to arrive at a design idea. The fourth phase is design transformation, and the fifth step is designed, which involves visualizing the design idea in working drawings and $3 \mathrm{D}$ as the final design.

\section{Result and Discussion}

\section{General Concept}

An apartment can be defined as a multi-story building with more than one floor. It collects several residential units, with each room unit having an entire living space, where the residents share the same facilities. (Arsitur Studio, 2020)

The green architecture approach to building design refers to the green building criteria of the Green Building Council Indonesia.

\section{Appropriate Site Development/ASD \\ 2. Energy Efficiency \& Refrigerant/EER \\ 3. Water Conservation/WAC \\ 4. Material Resources \& Cycle/MRC \\ 5. Indoor Air Health \& Comfort//HC \\ 6. Building \& Environment Management}

The shape of the building is processed with climatic and pragmatic concepts to find a form following the environmental conditions and following the climate in the area. (A, Aristia. Putri, m. Rohman, Arif. dan Utomo, 2021)

\section{Location}

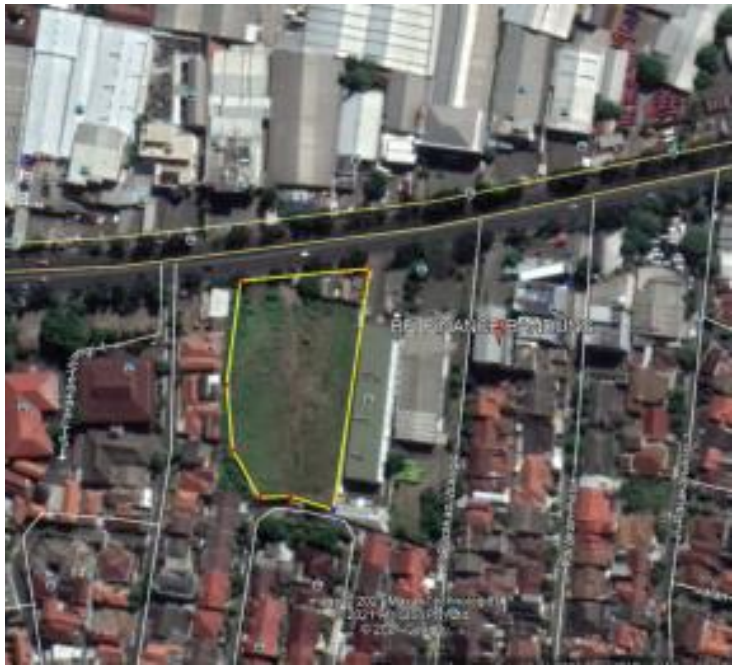

Figure 1. Location map

(Source: Google Earth Pro)

Location: Jl.Soekarno-Hatta, Batununggal,

Kec. Bandung Kidul, Bandung

City, West Java 40266

Large $: 6.335 \mathrm{~m}^{2}$

BCR : $6.335 \mathrm{~m} 2 \times 30 \%=1.900,5 \mathrm{~m} 2$ 
FAR $4.0 \quad: 6.335 \mathrm{~m} 2 \times 4=25.340$

GAC $60 \%: 6.335 \mathrm{M} 2 \times 60 \%=3.801 \mathrm{~m} 2$

Number of floors:12

(Source : RDTR Bandung City 2011-2031)

Land Boundary

- North, Jalan Soekarno Hatta

- South, Parakan Waas road

- East, Yamaha Flag ship Shop

- West, Hotel Parakan wangi \& PKK Building

Land Use

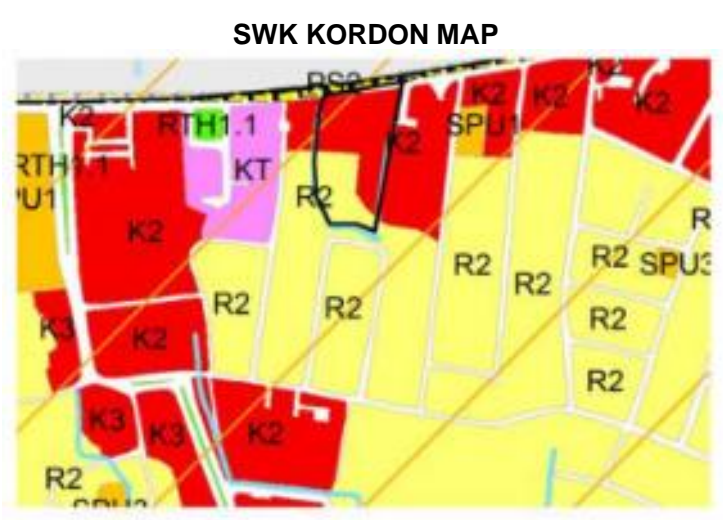

Figure 2. Land use

(Source: SWK Kordon Map)

The area around the site is a cultivation zone for a medium-density residential area, government offices, and a service trade cultivation zone.

\section{Geographical Conditions}

Geographically, the Batununggal subdistrict, Bandung Kidul Subdistrict, has a flat/undulating area of $100 \%$ of the total area. Judging from the ground level, subdistrict Batununggal is located at $500 \mathrm{~m}$ above sea level. The maximum and minimum temperatures in sub-district Batununggal. It ranges from 19-270C, while in terms of rain, it ranges from 240 $\mathrm{mm} / \mathrm{year}$, and the number of days with the most rainfall is 45 days.

\section{Land Analysis}

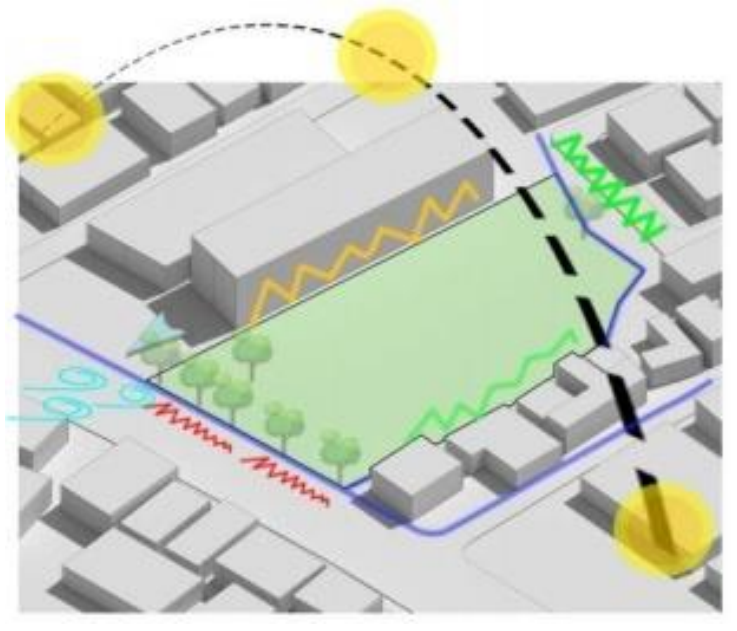

Figure 3. site analysis (Source: private document)

Noise Analysis

Problem

- Low noise on the west and south side

Car repair shops cause-Moderate noise in the east

- The high noise on the north side is due to the city artery road

\section{Response}

- zoning residential and office areas to the south so that the noise from the road is slightly reduced and does not interfere with the activities of residents and employees.

- plant some trees in the front area to buffer the sound from the road

\section{Siting Analysis of the Sun}

Land extending from north to south requires good building period formation and responding well to sunlight. If not paid attention, it can cause neglect problems in the building. Building openings must also maintain their comfort (Balaras, C. A., Droutsa, K., Argiriou, A. A., \& Asimakopoulos, 2000).

\section{Response}

- The building will use secondary skin to reduce the heat and glare of the afternoon sun.

- The building is angled slightly to create a shading effect. 


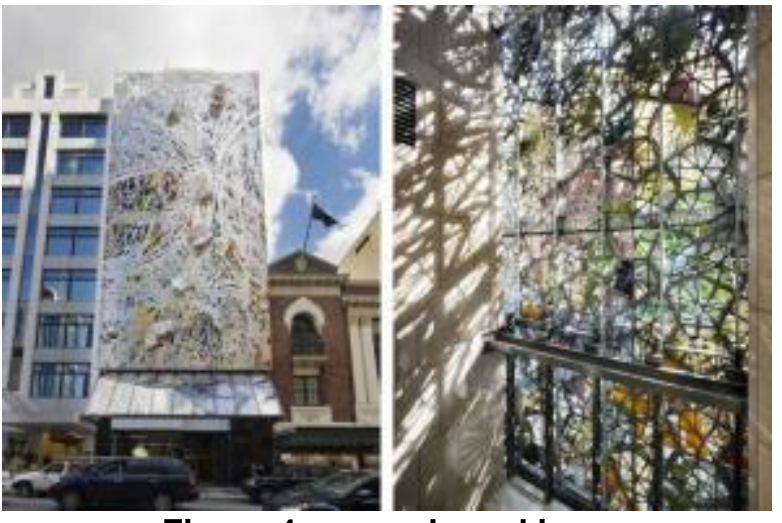

Figure 4. secondary skin

(Source: https://inhabitat.com/wpcontent/blogs.dir/1/files/2012/07/Wintergard en-Studio-505-7.jpg)

\section{Vegetation Analysis}

When viewed from the Google Earth satellite imagery, the land is a field that is not planted with trees, pretty shady trees are only on the edge of the land in the north, and one tree in the south.

\section{Response}

Planting lots of trees as an effort of greening and land conditioning.

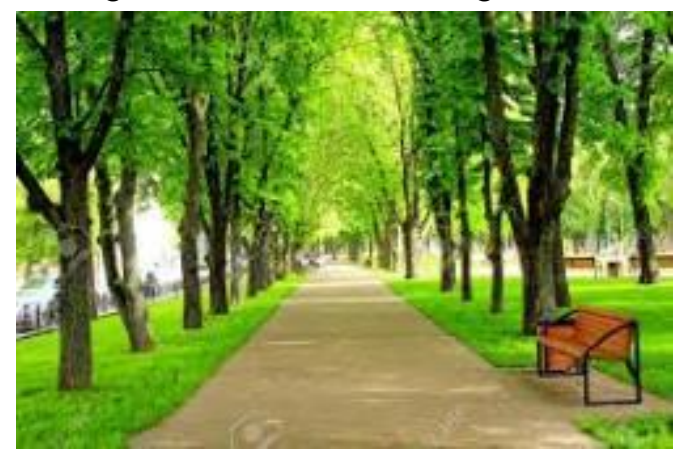

Figure 5. parks and trees

(Source: https://encrypted-

tbn0.gstatic.com/images?q=tbn:ANd9GcS3 QomTiHSbQ5Wup3fuYEVPOAkB7IXQiCBYX A\&usqp=CAU)

\section{Drainage Analysis}

Rainfall in the city of Bandung is relatively high. In the rainy season, the drainage channels are always total and even cause a flood, the drainage channel around the site, especially on the west side, is small drainage that borders Homes.

\section{Response}

I am creating retention ponds and infiltration wells to reduce water runoff directly leading to city drainage channels. The high price of land and the decreasing number of vacant land in urban areas make it difficult for immigrants and local people to buy houses and land in Bandung. Therefore, a vertical residential concept or apartment for residence is needed to solve the high cost and difficulty of vacant land in Bandung. The lack of availability of vacant land and the high price of land in urban areas is accompanied by several environmental problems such as increased waste, the greenhouse effect, floods, and others(Andiyan \& Nurjaman, 2021).

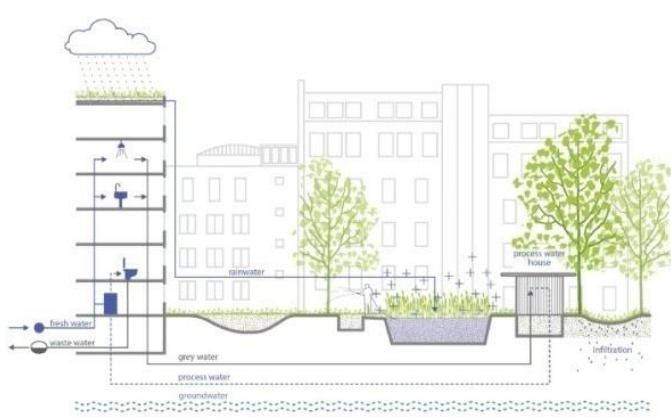

Figure 6. infiltration wells (Source:https://newberkeley.files.wordpres s.com/2016/01/ infiltration wells.jpg)

\section{Contextual Analysis}

Judging from the data of Kelurahan Batunggal, it is known that the most significant number of jobs include students/university students private employees, so that the building can be used and useful for the surrounding community, co-working space and microlibrary facilities are added, this function is also as a support for the priority education program of Batunggal sub-district. (Slezkine, 1994)

Judging from the data on Park entertainment facilities in Batununggal Village, there are only three pieces. With a 
relatively dense population, public spaces can help become community recreation choices.(Kwak, Min Jung, Yoo Suk Hong, 2007)

In addition, it can be seen from the data on sports facilities in Batununggal village that it does not yet have a basketball court for the general public. The basketball court can be added to public apartment facilities in Tamarah provides a jogging track for apartment residents and the community. The public space also functions as a performance space for art and cultural activists in the Batununggal sub-district. (Garcia, D. Astiaso, 2014)

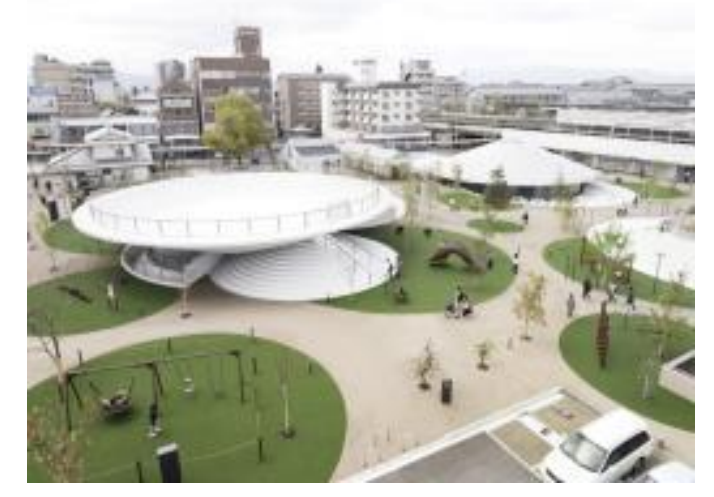

Figure 7. Public Area

(Source:https://inhabitat.com/wpcontent/blogs.dir/1/files/2017/06/CoFuFunby-Nendo-4-889x666.jpg)

\section{Concept of Design}

\section{Green Building}

\section{- Appropriate Site Development}

his category includes access to public facilities, reduced vehicles, Motorized rain, use of bicycles, landscaping green plants, heat island efficiency, reduction of the load volume of rainwater runoff, site management, attention to surrounding buildings or facilities. (Proulx, 1995)

\section{- Energy Efficiency and Conservation}

This category includes the optimization of the efficiency of energy use In buildings, recommissioning of air conditioning equipment, saving energy on lighting and air conditioning systems, recording And supervision of energy use, operation, and maintenance of air conditioning equipment, use of renewable energy, and reduction of energy emissions. (John, 1996)

\section{- Water Conservation}

The Water Conservation category includes sub-metering water consumption, maintenance and Checking the plumbing system, the efficient use of clean water, testing water quality, using recycled water, using the filtration system to produce drinking water, reducing the use of water from deep wells, and using kranauto stop. (Balaras, C. A., Droutsa, K., Dascalaki, E., \& Kontoyiannidis, 2005)

\section{- Indoor Health and Comfort}

This category includes indoor air quality, environmental regulation of cigarette smoke, monitoring $\mathrm{CO} 2$ and $\mathrm{CO}$ gases, measuring indoor air quality, size of visual comfort, measurement of sound levels, and survey of building comfort.(Cohen, S., Glass, D. C., \& Singer, 1973)

\section{- Material Resources and Cycle}

This category includes refrigerant use, friendly materials environment, waste management, waste sorting, hazardous waste management, and distribution of used goods. (Chau, K., Ma, V., \& Ho, 2001)

\section{Building Mass Concept}

Site size and shape

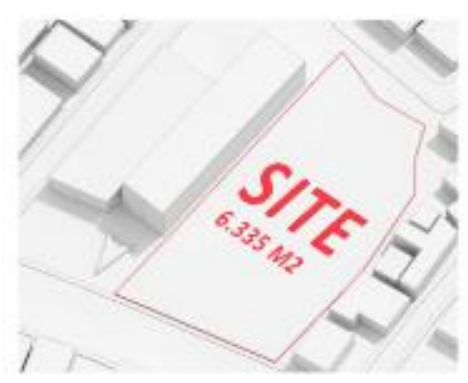

Figure 8. site

(Source: Private document) 
The area is built according to regulations

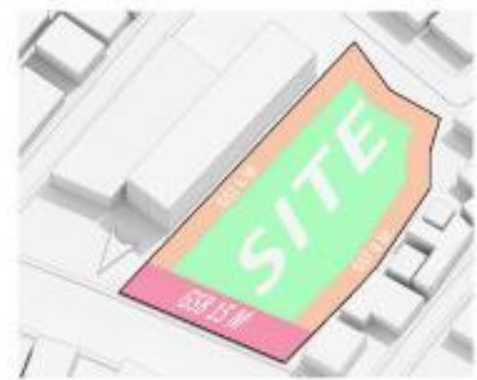

Figure 9. awakened area

(Source: Private document)

Added horizontal zoning

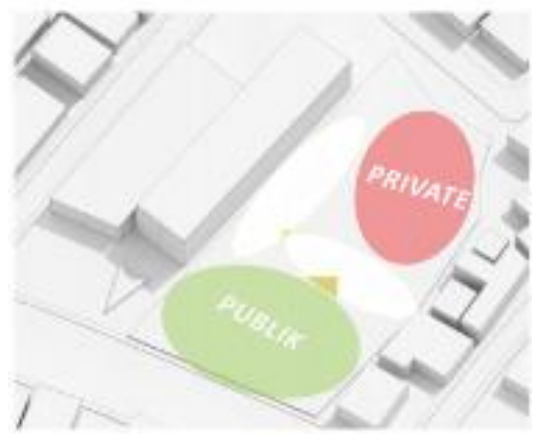

Figure 10.Zoning

(Source: Private document)

Addition of podium floors 1 and 2 apartments.

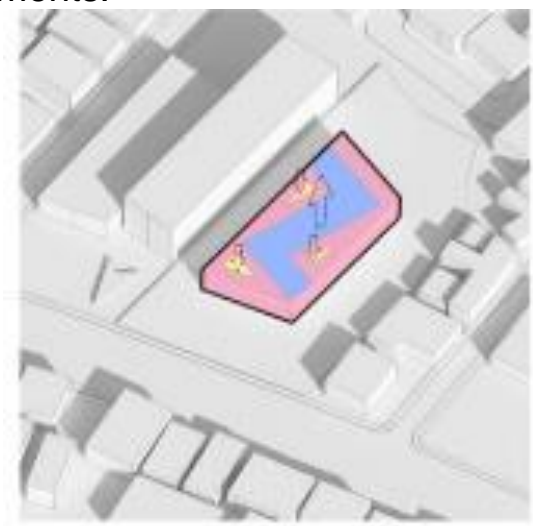

Figure 11. massing 1

(Source: Private document)

Additional apartment tower mass.

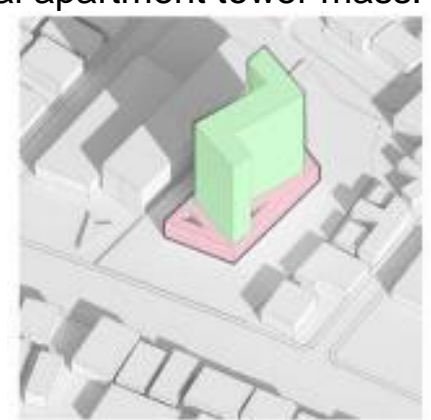

Figure 12. massing 2

(Source: Private document)
Additional areas to be planted with trees

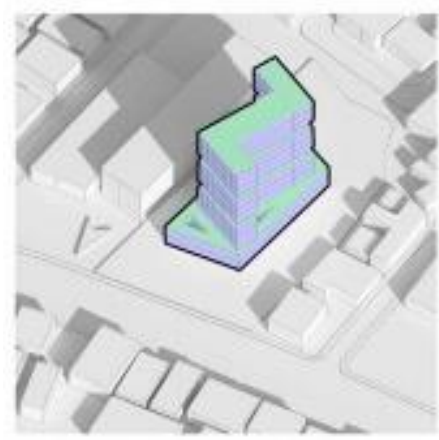

Figure 13. massing 3

(Source: Private document)

\section{Facade Concept}

The facade of this apartment building uses two concepts: the application of metal cladding as a second skin in the podium area and the concept of a tree as the building facade.

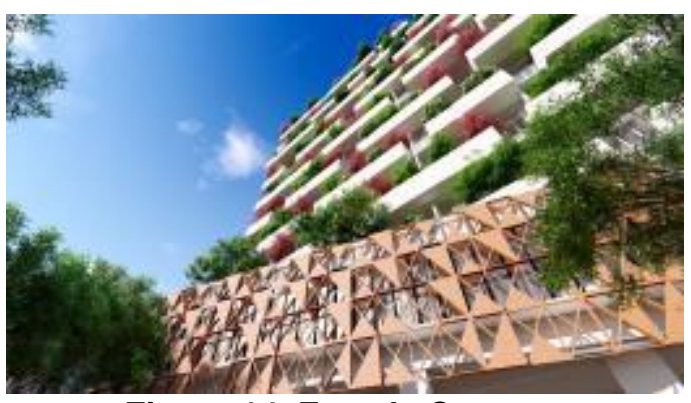

Figure 14. Facade Concept

(Source: Private document)

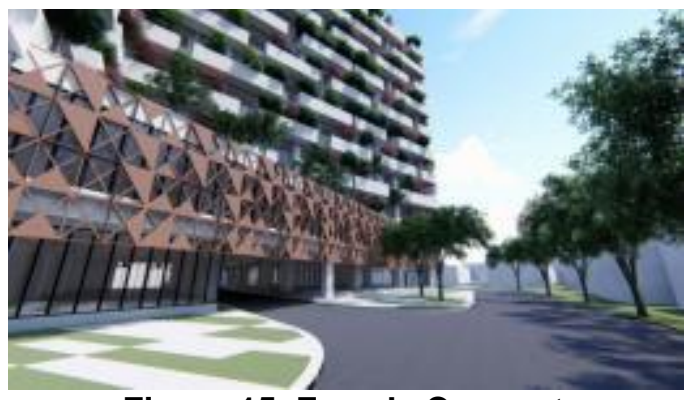

Figure 15. Facade Concept

(Source: Private document)

\section{Structure Concept}

The structural concept used is the rigid frame structure, a load-bearing frame with straight or curved members and is connected by most rigid joints, which withstand the motion induced in the movement of member's joints. The members can take bending, shear, and axial loads. 


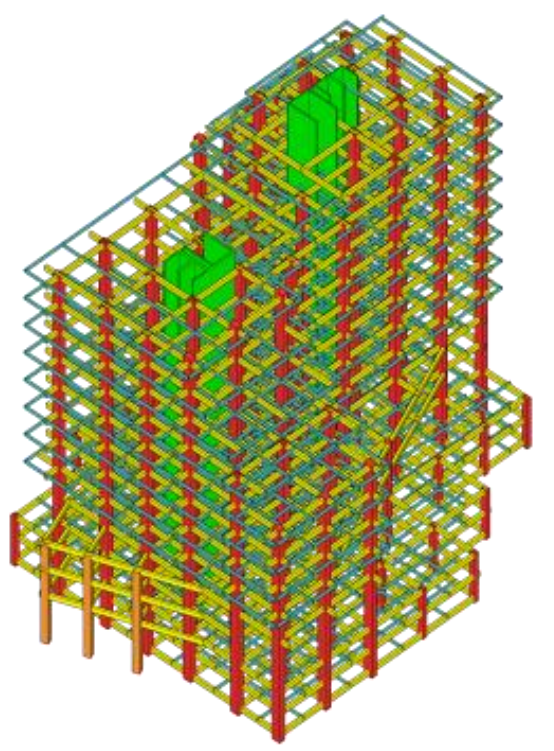

Figure 16. Structure Concept (Source: Private document)

\section{Conclusion}

The apartment Wanaka OTA was developed following the Indonesian Green Building Council's green building concept (GBCl). Wanaka translates as "City Forest," and trees influenced its name. This tree serves as a CO2 absorber and oxygen supply in the environment and is an attractive enhancement.

\section{References}

A, Aristia . Putri, m. Rohman, Arif . dan Utomo, Christiono. (2021). Penilaian Kriteria Green Building pada Gedung Teknik Sipil ITS. Jurnal Teknik ITS, 1(1).

Akmal, Imelda. (2007). Menata apartemen. Gramedia Pustaka Utama.

Andiyan,Nurrisman, Okki. (2021). Implementation of the New Function of the Sarinah Braga Building ( Hotel De Braga By Artotel ). Solid State Technology, (7).

Andiyan, Andiyan, \& Nurjaman, Andri. (2021). Pendekatan Urban Green Building Pada Bangunan Apartemen. RADIAL: Jurnal Peradaban Sains,
Rekayasa Dan Teknologi, 9(1), 39-52. https://doi.org/10.37971/radial.v9i1.21 8

Arsitur Studio. (2020). definisi Apartemen menurut para ahli.

Balaras, C. A., Droutsa, K., Argiriou, A. A., \& Asimakopoulos, D. N. (2000). Potential for energy conservation in apartment buildings. Energy and Buildings.

Balaras, C. A., Droutsa, K., Dascalaki, E., \& Kontoyiannidis, S. (2005). Energy and Buildings.

Chau, K., Ma, V., \& Ho, D. (2001). The pricing of "luckiness" in the apartment market. Journal of Real Estate Literature.

Cohen, S., Glass, D. C., \& Singer, J. E. (1973). Apartment noise, auditory discrimination, and reading ability in children. Journal of Experimental Social Psychology.

Garcia, D. Astiaso, et al. (2014). Ecoarchitecture, and sustainable mobility: An integrated approach in Ladispoli town. WIT Transactions on the Built Environment.

John, B. (1996). Mass transportation, apartment rentals, and property values. Journal of Real Estate Research.

Kwak, Min Jung, Yoo Suk Hong, and Nam Wook Cho. (2007). Eco-architecture analysis as a method of end-of-life decision making for sustainable product design. International Design Engineering Technical Conferences and Computers and Information in Engineering Conference, 48043.

Proulx, G. (1995). Evacuation time and movement in apartment buildings. Fire Safety Journal.

Slezkine, Y. (1994). The USSR as a communal apartment, or how a socialist state promoted ethnic particularism. Slavic Review. 